\title{
Predicting Aquifer Storage Properties Integrating Geoeletric Methods with Dynamically Derived Geomechanical Parameters in Parts of Cross River State, Nigeria
}

\author{
Fidelis Ankwo Abija ${ }^{1,2}$ \\ ${ }^{1}$ Centre for Geomechanics, Energy and Environmental Sustainability, Port Harcourt, Nigeria \\ ${ }^{2}$ Institute of Geosciences and Space Technology, Rivers State University, Port Harcourt, Nigeria
}

Email address:

fidelabija@yahoo.co.uk

\section{To cite this article:}

Fidelis Ankwo Abija. Predicting Aquifer Storage Properties Integrating Geoeletric Methods with Dynamically Derived Geomechanical Parameters in Parts of Cross River State, Nigeria. American Journal of Water Science and Engineering. Vol. 5, No. 4, 2019 , pp. 174-183. doi: 10.11648/j.ajwse.20190504.15

Received: December 9, 2019; Accepted: January 8, 2020; Published: February 11, 2020

\begin{abstract}
Predicting subsurface rocks' storage properties is a fundamental problem of groundwater prospecting and potential evaluation for planning of long term abstraction wells. Water in aquifers is stored and or released from elastic storage and gravity drainage. Aquifer storage parameters are traditionally determined from pumping tests data which are seldom available until wells have been drilled. Confined aquifer storativity (S) is estimated as a function of rock lithology and thickness of the aquifer using the rule of thumb equation $\mathrm{S}=3.0 \times 10^{-6} \mathrm{~b}$, but $\mathrm{S}=\mathrm{S}_{\mathrm{s}} \mathrm{b}$ neglecting the effect of porosity and compressibility. The storativity equation assumes that all aquiferous rocks have a constant specific storage even though specific storage is directly dependent on rock porosity and most importantly rock grain compressibility which differs with lithology. In this study, apparent resistivity data derived from field resistance measurements in 31 locations were interpreted to infer geolectric layers lithologies and thicknesses. To determine the rock grain compressibility for computation of the specific storage, vertical stress at the aquifer depth was estimated using average densities of the interpreted subcrustal rocks. Results show that rock mineral grain compressibility varies from $7.915 \times 10^{-7}$ to $9.235 \times 10^{-5} / \mathrm{Pa}$, porosity from 0.08 to 1.64 with the weathered overburden and sandstones having the higher porosities; specific storage vary from $8.32 \times 10^{-6}$ to $1.80 \times 10^{-3}$ and storativity ranges from $3.161 \times 10^{-6}$ to $1.96 \times 10^{-3}$. Clearly, results indicates that the specific storage differ predictably with rock type and consequently the storativity of the different aquifers.
\end{abstract}

Keywords: Aquifer, Geoelectric Layers, Geomechanics, Specific Storage, Storativity

\section{Introduction}

Aquifer storage properties are important for understanding hydraulic response to transient stresses on the groundwater bearing rock units. Specific storage is the fluid released from storage per unit decline in hydraulic head per unit bulk volume under conditions such that there is no strain in two orthogonal directions and the total normal stress in the third orthogonal direction is constant. This definition applies to general isotropic three dimensional elasticity of any representative elemental rock volume. It is a point property and is independent of the problem domain stress and head boundary conditions [1]. Water in a porous rock is stored and or released from elastic storage and from gravity drainage [2]. Aquifer specific storage and storativity may vary spatially because of geologic heterogeneity and estimation of these properties allow for quantitative prediction of the hydraulic response of the aquifer to recharge and pumping.

Storage properties are often estimated on a local scale by analysis of borehole pumping well tests data using single well or multiple-well aquifer tests, or on a regional scale by numerical simulation methods. Local scale variation ranges from tens to hundreds of feet while the regional scale is characterized by lengths of hundreds to thousands of feet.

Whereas surface water occurs readily in drainage basins 
with boundaries determined by topography, groundwater occurs in subsurface rocks that possess the capacity to store and transmit it at rates fast enough to supply reasonable amounts to wells. Groundwater divides do not coincide with those of surface water thus groundwater management is dependent on its mode of occurrence and the hydraulic characteristics of the aquifer. Groundwater storage, transmission and consequently abstraction through wells constitute the groundwater potential. Its yield and abstraction depends on the position, thickness and lithology of the reservoir and confining beds as well as their hydraulic characteristics of the aquitards, and the amount of groundwater withdrawal [2].

[3] Developed a method of estimating confined aquifers storativity based on lithology and thickness alone; and stated that aquifer transmissivity can be estimated from specific capacity but specific storage and storativity are not readily obtainable. In his proposition,

Prospecting for groundwater as a pre-requisite for siting productive abstraction wells especially in crystalline basement environments has always been a challenging issue as hydrogeologists are faced with the problem of having to predict aquifer behavior in the midst of paucity of data.

The use of geophysical methods which probe into the earth's subsurface is adopted based on the mode of geological occurrence and geoelectric survey methods in groundwater prospecting have been in existence globally for over 200 years [4].

The application of geomechanics principles in the determination of aquifer hydraulic characteristics has not received adequate attention. This approach was adopted in this study because one of the parameters required for calculating the specific storage of an aquifer, the rock grain compressibility can be determine using geomechanical approach.

The study area is a crystalline basement terrain overlain by consolidated sandstones, shales, siltstones and granitic weathered zone with a history of abortive boreholes most producing from a thin overburden.

[5] In his study on basement aquifers of Africa submitted that a minimum overburden thickness varying from $20-25 \mathrm{~m}$ is required for siting boreholes in crystalline basement regions as chemical weathering can produce saprolitic regolith with porosities of $40-50 \%$ and specific yield of 15 $-30 \%$ thus forming good aquifers.

A key factor in groundwater occurrence is the presence of porosity and or permeability [6]. Sandstone aquifers may have porosities of $<30 \%$ due to their compaction and or consolidation. In extreme cases, porosity can be $<1 \%$ and hydraulic conductivities can range in the region of that of unfractured rocks i.e. $<10^{-10} \mathrm{~m} / \mathrm{s}$.

Pre-drilling hydrogeologic and geophysical assessment and hydraulic characterization of groundwater aquifers can help in predicting the subsurface water supply potential of an aquifer system when boreholes for pumping tests have not been drilled. This research was commissioned to investigate and proffer solution to the problem of abortive boreholes most of which are abstracting from the thin weathered overburden. In achieving the goal, integration of vertical electrical sounding (VES) data with estimated geomechanical properties such as vertical stress, bulk and rock grain compressibilities, Biot coefficient; porosity and formation factor was adopted in predicting the aquifer hydraulic characteristics, their protective capacity and groundwater potential of the area.

\section{Study Area}

The study area is underlain by cretaceous sediments of the Cross River plain and the basement complex region of South Eastern Nigeria (figure 1) [7, 8]. It forms part of the two spurs of the Precambrian basement complex, the Obudu plateau and the Oban massif of South East Nigeria. The Obudu plateau and Oban massif have been reported by [42] as prolongation of the Cameroon hingeline into Nigeria linked with Benue trough. This basement rocks are overlain by the cretaceous sediments of the calabar flank but separated by the Mamfe embayment which is a filled grabben in the North of the State [9], Dominant rock types include phyllites, schists, gneisses, granulites and migmatites intruded by granitic, mafic and ultramafic rocks. They range in age from NeoArchaean to Pan-African [10]. The characteristic rock types are a fluviatile clastic point bar fining-upward sequence and over bank mudrocks belonging to the Asu River Group of Albian age [11]. The Mamfe rift composed of sedimentary rocks occurs in association with jointed basaltic rocks and the type locality of the Mamfe Formation is on the bank of Cross River at Mamfe in adjoining Cameroon Republic where $800 \mathrm{~m}$ of massive arkosic sandstones with marl, sandy limestone and shale intercalations are exposed [12]. The sequence in the Nigerian part of the Mamfe Basin comprises conglomeritic immature mudstones [13] with evidence of faulting [14]. The cretaceous sediments have been intruded by granitic, granodioritic, doleritic and basaltic rocks. The cretaceous sediments compositionally made of compacted to consolidated sandstones, siltstones, shales, and mudstones outcrop in the area. Thin compacted clay units exist within the mudstones layers, and occasionally sandwiched by shales and sandstones are exposed in Igbo Imabana, Assiga, Ababene, Ekpeti and Adim within th Cross River plain. The rock types exposed within geologic formation are principally compacted to consolidated sandstone, siltstone, shales, basalts, dolerites, and crystalline granitic rocks. Ijutum is covered by igneous intrusive rocks. The crystalline basement complex rocks are overlain by the cross river plain. The crystalline basement rocks appear to be buried covered by the consolidated sediments of Cross River plain in well over of $85 \%$ of the Akarefor. Akpet Central lies within the granitic basement formation of S. E Nigeria. The hydrology of the area reflects a typical rain forest environment with dendritic rivers and streams. Prominent amongst the rivers and streams draining the area the Cross River, rivers Lokpon, Okwo, Okerekwu, Udip, Udam. Minor streams like Lekpoi, Ebehe 
in Igbo Imabana, Lemene, Ugom flowing in Akpet Central, Iwusu stream Egbono stream in Akarefor; and Lekwo in Ekpeti. The directions of flow which are either east or west depend on the local slope of the area. Though numerous seasonal streams and ponds exist in the communities of study; about $95 \%$ of the available surface water is impure for human consumption.

\section{Method of Study}

Field methods involved geological, hydrogeological and electrical resistivity depth sounding investigations. ABEM Terrameter SAS 300C, a simple resistivity meter with potentiometric arrangement was used for measurement of field resistance. In this method, depth investigations were made as a basis for inferring the vertical succession of different conducting rock units in the subsurface in terms of their inferred lithology, thickness and resistivity. Depth penetration was achieved by simply introducing current into the subsurface using galvanic contact. Generally, four steel terminal electrodes are used to minimize the effect of material contacts and in carrying out the survey, direct current or very low frequency $(<1 \mathrm{~Hz})$ current was introduced into the ground through two steel electrodes (current electrodes), A and B which set up a potential difference in the ground.

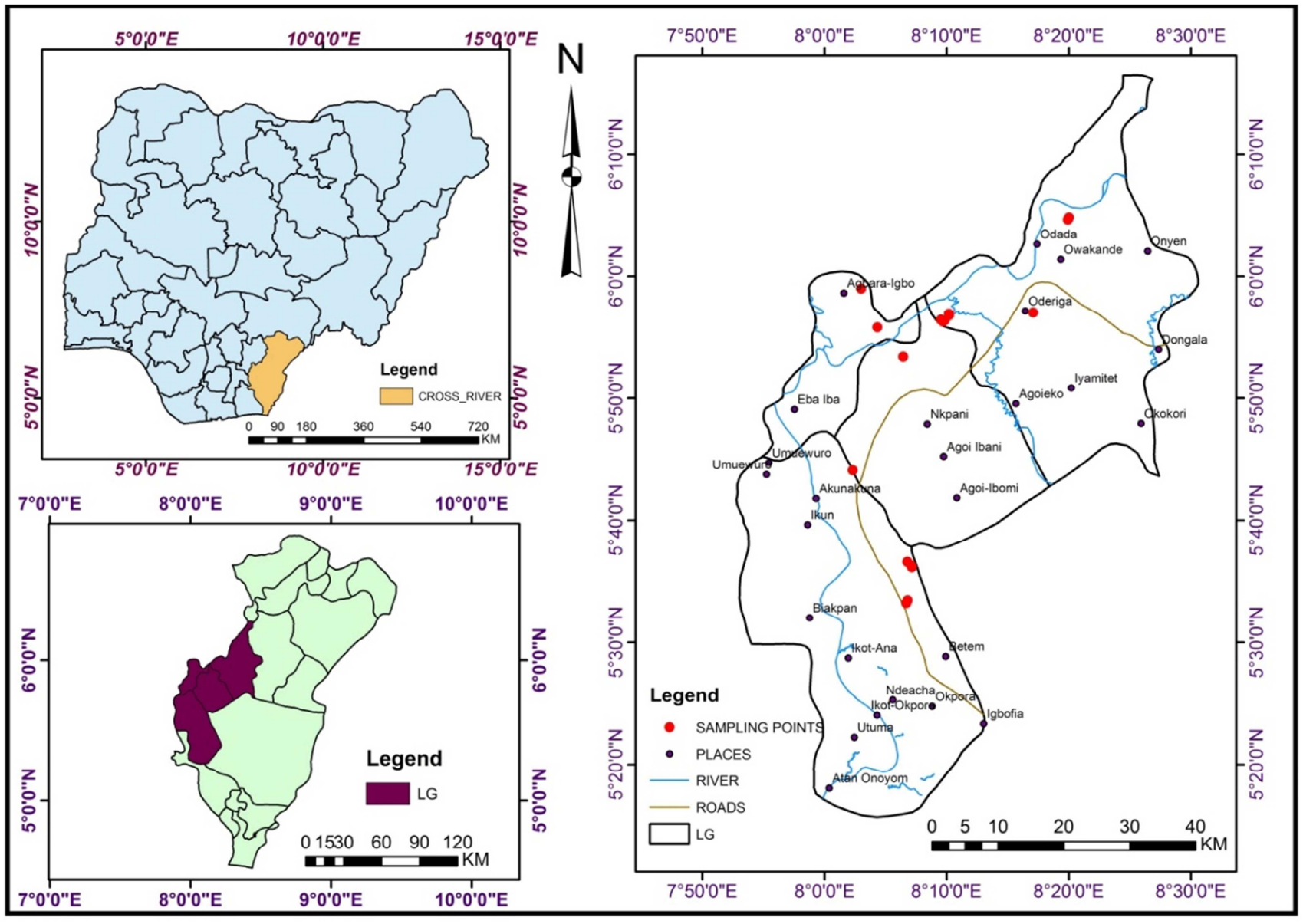

Figure 1. Map of study area showing study locations.

This potential difference is measured between a second pair of steel electrodes (the potential electrodes), $\mathrm{M}$ and $\mathrm{N}$. The four electrodes, A-M-N-B are kept in a straight line such that $\mathrm{AB} \geq 5 \mathrm{MN}$ in accordance with the Schlumberger electrode array. A total of 31 vertical electrical soundings (VES) were conducted within 11 communities. The electrode spread varies from 600 - 1000 metres depending on accessibility and strike of rock formations.

\section{Data Analyses}

Geo-electric Survey Data

Apparent resistivities of the subsurface layers in ohms- meter were calculated from the measured field resistance values using equation (1)

$$
\rho_{\mathrm{a}}=\mathrm{GR}
$$

For the Schlumberger array of resistivity survey adopted for this study, the apparent resistivity was calculated using equation (2) [2]

$$
\rho_{\mathrm{a}}=\pi \mathrm{R} \frac{(\mathrm{AB} / 2)^{2}-(\mathrm{MN} / 2)^{2}}{(M N)}
$$

$\rho_{\mathrm{a}}=$ apparent resistivity, geometric factor dependent on electrode configuration, $\mathrm{R}=$ field resistance $(\mathrm{R}=\Delta \mathrm{V} / \mathrm{I}), \mathrm{AB}$ 
$=$ current electrode spacing, $\mathrm{MN}=$ potential electrode spacing and $\pi=$ constant.

The apparent resistivity results obtained are plotted against half the current electrode spacing in meters in a double logarithmic curve using the Zohdy computer software programme and interpreted quantitatively to obtain the type curves and subsurface geoelectric models. Quantitative data analysis was carried out to infer the substrata sequences; their thickness, depth to layers and the respective resistivity.

\section{Aquifer Storage Properties}

Specific Storage

This is the amount of water per unit volume of a saturated formation stored or expelled from storage due to compressibility of the mineral rock skeleton and pore water per unit change in head. It is also called elastic storage coefficient and is given by equation (3) [15].

$$
\mathrm{S}_{\mathrm{s}}=\rho_{\mathrm{w}} \mathrm{g}\left(\mathrm{C}_{\mathrm{g}}+\phi \beta\right)
$$

where $\rho_{\mathrm{w}}=$ density of water, $\mathrm{g}=$ gravitational acceleration, $\mathrm{C}_{\mathrm{g}}=$ rock grain compressibility, $\phi=$ rock porosity and $\beta=$ compressibility of water $=4.8 \times 10^{-10} \mathrm{~m}^{2} / \mathrm{N}$

\section{Storativity}

The storativity (S) (also called storage coefficient) of an aquifer of a confined aquifer is the product of the specific storage $\left(\mathrm{S}_{\mathrm{s}}\right)$ and the aquifer thickness (b) expressed in equation (4).

$$
\mathrm{S}=\mathrm{bS}_{\mathrm{s}}
$$

However, confined aquifer storativity $(\mathrm{S})$ is estimated as a function of rock lithology and thickness of the aquifer using the rule of thumb equation (5) [16]; [17].

$$
\mathrm{S}=3.0 \times 10^{-6} \mathrm{~b}
$$

This equation implies that the constant $\left(\begin{array}{llll}3.0 & \mathrm{x} & 10^{-6}\end{array}\right)$ represents the specific storage $\left(\mathrm{S}_{\mathrm{s}}\right)$ in equation (5) and equation neglects the effect of porosity and compressibility. It assumes that all aquiferous rocks have a constant specific storage even though it is directly dependent on rock porosity and most importantly rock grain compressibility which both differs with lithology. Groundwater is stored and released from elastic storage and rock elasticity depends on the compressibility and porosity. This necessitates that the aquifer compressibility and porosity be determined for evaluation of the specific storage. Geomechanical properties of subsurface rocks are determined from static tests on cores retrieved from the boreholes during drilling. However, rock cores are seldom available during groundwater prospecting thus the use of dynamic methods which rely on geophysical data. In this method, vertical electrical sounding was conducted and geolectric layers interpreted with their thicknesses, depth and inferred lithology and results used in determination of rock grain compressibility and porosity as input into equation (3) by [15].

Determination of Geomechanical Properties of Aquiferous Rocks

As input into equation (3), it is required to determine the rock grain compressibility and porosity. Rock grain compressibility $\left(\mathrm{C}_{\mathrm{g}}\right)$ (in $\left./ \mathrm{Pa}\right)$ is the change in rock matrix volume per hydrostatic pressure due to the average weight of compressible mineral grains of the rock with zero porosity. It is a function of the bulk compressibility and is given as

$$
\mathrm{C}_{\mathrm{g}}=(\alpha+1) \mathrm{C}_{\mathrm{b}}
$$

The bulk compressibility $\left(\mathrm{C}_{\mathrm{b}}\right)(\mathrm{in} / \mathrm{Pa})$ of an aquiferous rock is the unit change in volume over change in pressure $(\Delta \mathrm{V} / \mathrm{V} \Delta \mathrm{P})$ for a porous rock. Bulk compressibility with porosity is volumetric deformation per hydrostatic pressure and is the inverse of bulk modulus of the rock. It is given as

$$
\mathrm{C}_{\mathrm{b}}=\frac{1}{V_{b}} \frac{\mathrm{dV}_{b}}{\mathrm{~d} \sigma_{z}}
$$

Rock compressibility and compaction occurs in the vertical direction due to gravity loading of the overburden subcrustal lithostatic materials thus is given in equation (4) as,

$$
\mathrm{C}_{\mathrm{b}}=\frac{1}{h} \frac{d h}{\mathrm{~d} \sigma_{z}}
$$

where $\mathrm{V}_{\mathrm{b}}=$ bulk volume of the rock, $\sigma_{\mathrm{z}}=$ vertical stress at depth $\mathrm{z}, \mathrm{h}=$ original reservoir thickness, $\mathrm{z}=$ depth [18].

\section{Determination of the Magnitude Vertical Stress}

The vertical stress (in mpa) at each depth $\mathrm{z}$, is an input parameter in the determination of rock grain compressibility. It was estimated using equations (9) by substituting average rock densities (Table 1) of interpreted rock layers and integrating from the surface to depth of interest. Results of the vertical stress determined from equation (6) were compared with those calculated using the [19] equation (10) for its prediction. Correlation of the magnitude of the vertical stress using the two equations yielded equation (11) which was used for predicting the vertical stress in the study location with a correlation coefficient $\left(\mathrm{R}^{2}\right)$ of 0.9972 (Figure 2).

Table 1. Average densities of subcrustal rocks [20].

\begin{tabular}{ll}
\hline Rock & Average Density $\left(\mathbf{g} / \mathbf{c m}^{3}\right)$ \\
\hline Overburden & 1.92 \\
Sandstone & 2.35 \\
Shale & 2.40 \\
Granite & 2.64 \\
Basaltic rock & 2.99 \\
\hline \multicolumn{3}{c}{$\sigma_{\mathrm{z}}=\int \rho g d z$} \\
\\
$\sigma_{\mathrm{z}}=0.027 \mathrm{z}$ \\
& $\sigma_{\mathrm{z}}=0.9583(0.027 \mathrm{z})-0.024$
\end{tabular}

\section{Biot's Coefficient}

Porous rocks in the subsurface are undergo elastic deformation under poroelastic and conditions effective stress [21]. Effective stress due to pore water pressure counteract the total applied stress and to account for the resistance of the rock frame against the deformation of the subsurface rocks as the pore water pressure changes, [22, 23] introduced a coefficient $(\alpha)$ termed Biot's constant or coefficient into 
Terzaghi's equation. This constant is strongly dependent on the rock compressibility, bulk modulus and porosity. [24], [25] proposed equation (12) for Biot's coefficient based on the compressibility of the rock grain and bulk volume.

$$
\alpha=1-\mathrm{Cg} / \mathrm{C}_{\mathrm{b}}
$$

[26] Proposed an empirical relationship (eqn. 13) for Biot's coefficient based on the rock's porosity $(\phi)$ as

$$
\alpha=1-(1-\phi)^{3 /(1-\phi)}
$$

\section{Formation Factor and Porosity}

[27] Proposed that for a clean, water bearing formation implying one with no appreciable amount of clay and no hydrocarbons, its resistivity is proportional to the brine with which it is saturated. The proportionality constant is called the formation factor $(\mathrm{F})$ is given as (eqn. 14)

$$
\mathrm{F}=\rho_{0} / \rho_{\mathrm{w}}
$$

where $\rho_{0}=$ specific resistivity of the water saturated sand/sandstone, $\rho_{\mathrm{w}}=$ groundwater resistivity (fresh water $=$ 20 [28] and $\mathrm{F}=$ intrinsic formation factor..

Formation factor combines all properties of the material influencing electrical current flow such as porosity, pore shape and diagenetic cementation. According to [27], formation factor $(\mathrm{F})$ is given as (eqn. 15)

$$
\mathrm{F}=\mathrm{a} / \phi^{\mathrm{m}}
$$

where $\mathrm{a}=$ electrical tortuosity, $\phi=$ porosity and $\mathrm{m}=$ cementation factor.

For compacted sandstones, [29] proposed equations (16) and (17) from practical cases for formation factor and porosity respectively.

$$
\begin{aligned}
& F=1 / \phi^{2} \\
& \phi=(1 / F)^{1 / 2}
\end{aligned}
$$

\section{Results and Discussion}

\section{Geoelectric layers}

The interpreted subsurface lithologies, thicknesses and depth of occurrence are presented in (Table 2). Interpreted aquifer lithologies include weathered regolith, fractured shale and sandstones of the cretaceous sediments of the Cross River Plain. Resistivity results depicted 3 to 6 geoelectric subsurface earth layering across the study locations. The first and topmost geoelectric layer range in thickness from 0.4 to $10.1 \mathrm{~m}$ with resistivity varying from $9.94-1382.8 \Omega \mathrm{m}$ and forms the weathered regolith while layer 2 vary in thickness from $1.6-28.27 \mathrm{~m}$ and resistivity from $3.03-2628.5 \Omega \mathrm{m}$. The thickness of layer 3 varies from $2.1 \mathrm{~m}$ to infinity in places with resistivity of $1.6-3507.6 \Omega \mathrm{m}$. This layer forms the crystalline basement complex in seven of the study locations occurring in Araragha, Ofombongha, Ogada (locations 1 and 2), Ilike, Akpet number 1 and Ezzomozu. The basement complex rocks of layer 3 recorded the high resistivity values of this layer. The fourth geoelectric layer occurs and extends to infinity in Igbo Imabana, Mboti, Ijutum, Ababene, Ekpeti, Assiga, Akpet Central (locations 1, 2 and 3), Adim location 1, Ikpelewha 2 and Akpet Number 2. The layer resistivity varies from $7.4-6,711.54 \Omega \mathrm{m}$, the lower values recorded in areas where more than 4 geoelectric subsurface layering occur. Five geoelectric subsurface earths layering occurred in Okpame 1 and 2, Adadama, Akarefor and Ikpelewha location 1 with thickness range of $6.4 \mathrm{~m}$ to infinity and resistivity of $21.7-13338.36 \Omega \mathrm{m}$ in areas underlain by basement complex rocks. Ilike depicted a six geoelectric earths subsurface which is infinite in extent with a layer resistivity of $444.8 \Omega \mathrm{m}$ (Table 2).

\section{Geomechanical and Storage Properties}

The results of evaluation of the geomechanical and storage properties of the rock units are presented in (Table 3). The vertical stress ranges from $0.23 \mathrm{Mpa}$ to $2.04 \mathrm{Mpa}$ at a depth of $65 \mathrm{~m}$ and the stress magnitude varies with rock lithology indicating the influence of rock density. Bulk compressibility varies from $9.01 \times 10^{-7}$ to $0.70038 / \mathrm{Pa}$ while the rock grain compressibility ranges from $8.84 \times 10^{-7} / \mathrm{kPa}$ to $1.28392 / \mathrm{kPa}$. The highest grain compressibility value occurred in the fractured shale which porosity was 0.51 yielding the highest specific storage value of 10.52 and storativity of 219.7 . The bulk compressibility of the sandstones ranges from $9.01 \times 10-7$ to $1.02 \times 10-6 / \mathrm{kPa}$, grain compressibility from $8.84 \times 10^{-7}$ to 1.09 $\times 10^{-6} / \mathrm{kPa}$. Sandstone porosity varies from 0.22 to 0.36 yielding specific storage range of $8.67 \times 10^{-6}$ to $1.073 \times 10^{-5}$ and storativity range of 0.0005 to 0.0004 (Table 3 and Figure 3 ). The weathered saprolites recorded bulk compressibility of $8.55 \times 10^{-}$ ${ }^{7}$ to $1.23 \times 10^{-6} / \mathrm{kPa}$, grain compressibility of $1.26 \times 10^{-6}$ to $8.3 \times$ $10^{-5} / \mathrm{kPa}$, porosity of 0.25 to 0.96 , specific storage of $1.71 \times 10^{-5}$ to $2.02 \times 10^{-5}$ (Table 3 and Figure 3 ) and storativity ranging from 0.0006 to 0.0 .0008 (Table 3 and Figure 4). The porosity, specific storage and storativity make these weathered regoliths good aquifers. A percentage difference up to $130 \%$ was obtained between the specific storage predicted in this study and the constant term $\left(3.0 \times 10^{-6}\right)$ in all the aquifers (Figure 4). The storativity estimated as a product of the layer thickness and the constant, $3.0 \times 10^{-6}$ (Lohman; 1972; Todd; 1980) varies from 0.000001 to 0.00045 (Figure 9). The storativity estimated by this method is therefore misleading. This is because different rock types with or without fractures, posses' characteristic porosities and compressibilities. A correlation of the rock grain compressibility with specific storage depicts a direct proportionality with a coefficient of 1 (Figure 6). Porosity and Biot coefficient correlated well with a coefficient of 0.99 (Figure 7), while Formation factor and Porosity (Figure 8) correlation coefficient was -1 all showing strong correlations. The Correlation of aquifer specific storage with storativity (Figure 9) was a strong curvilinear polynomail relation with a cofficient of 1. All th correlation coefficients indicates that the geomechanical parameters estimated using the interpreted rock lithologies, layer thicknesses and depths are reliable and can be used in predicting the aquifer storage properties. 


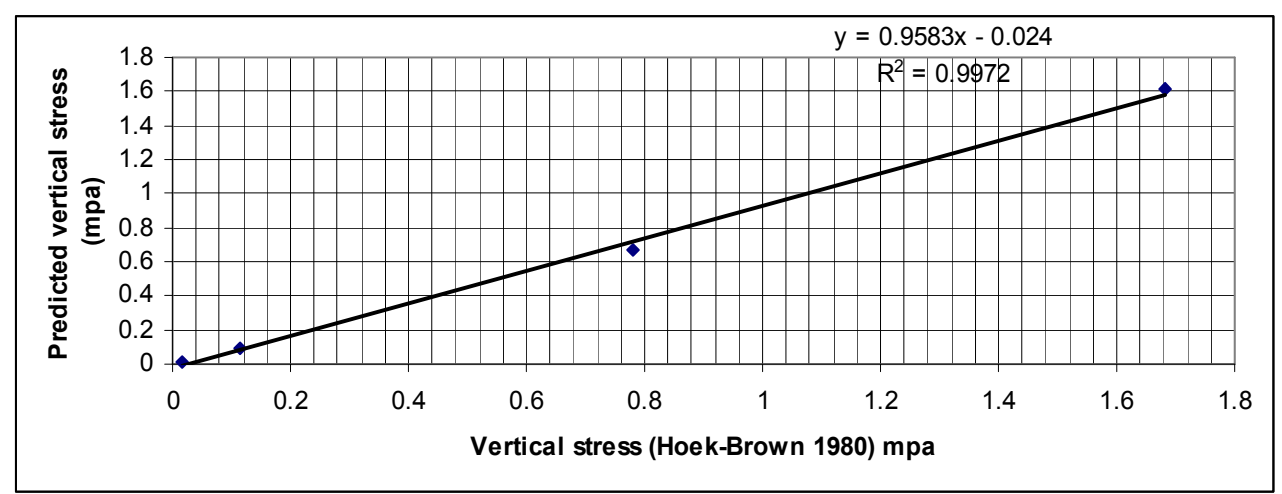

Figure 2. Variation of predicted vertical stress with Vertical stress determined using Hoek-Brown equation.

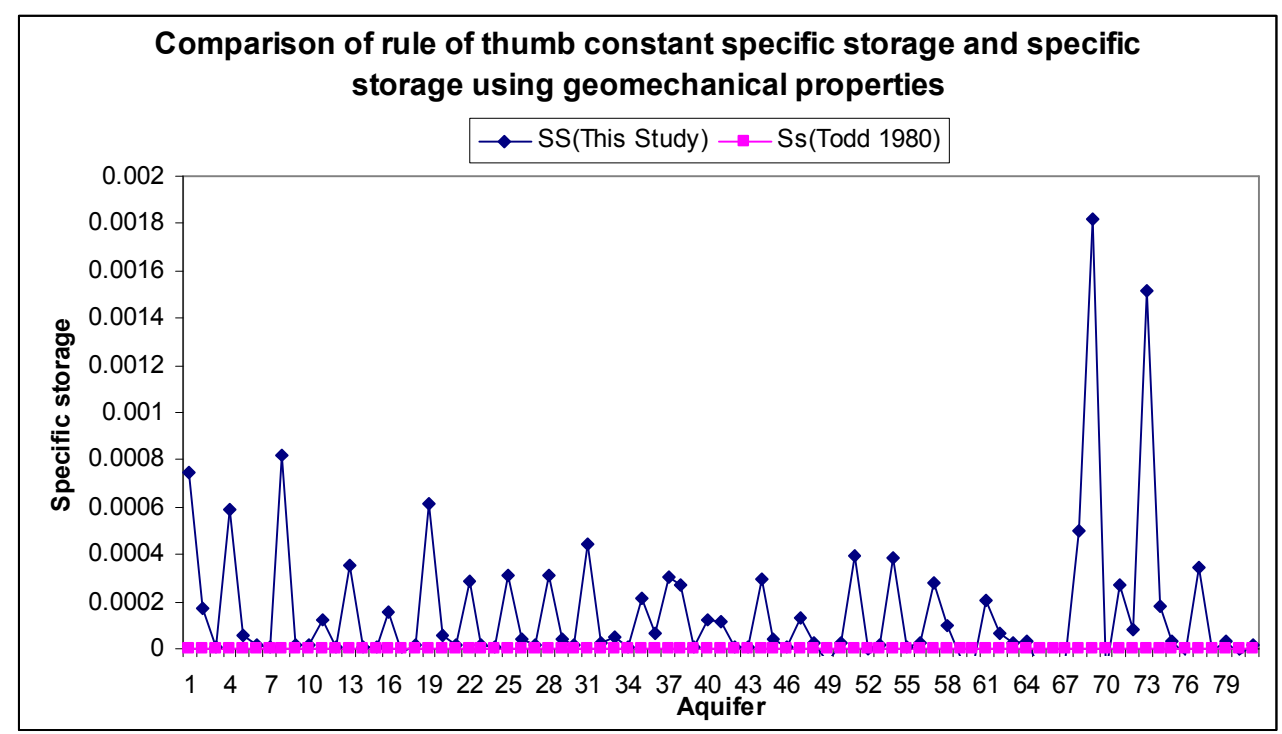

Figure 3. Comparison of specific storage determined from this study with constant term, $3.0 \times 10^{-6}$ of [17, 18$]$.

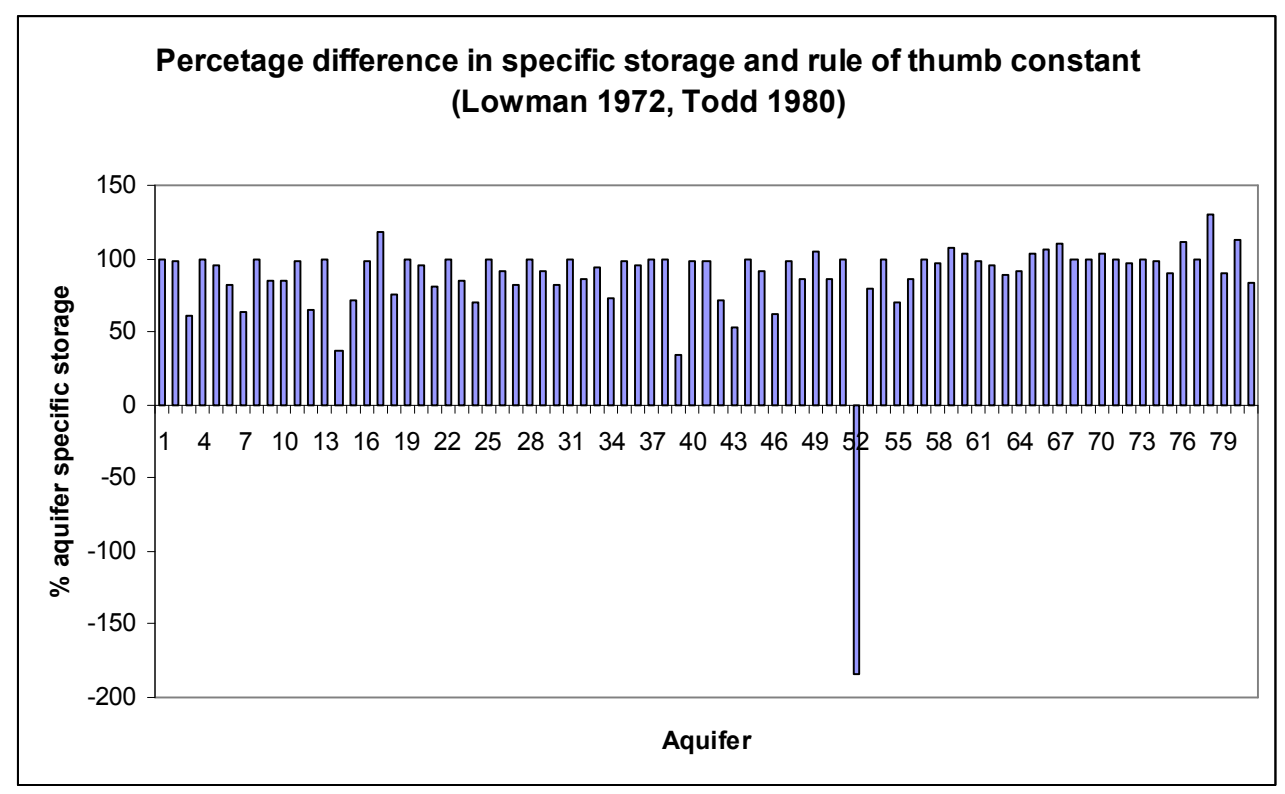

Figure 4. Percebtage difference between predicted specific storage and constant. 


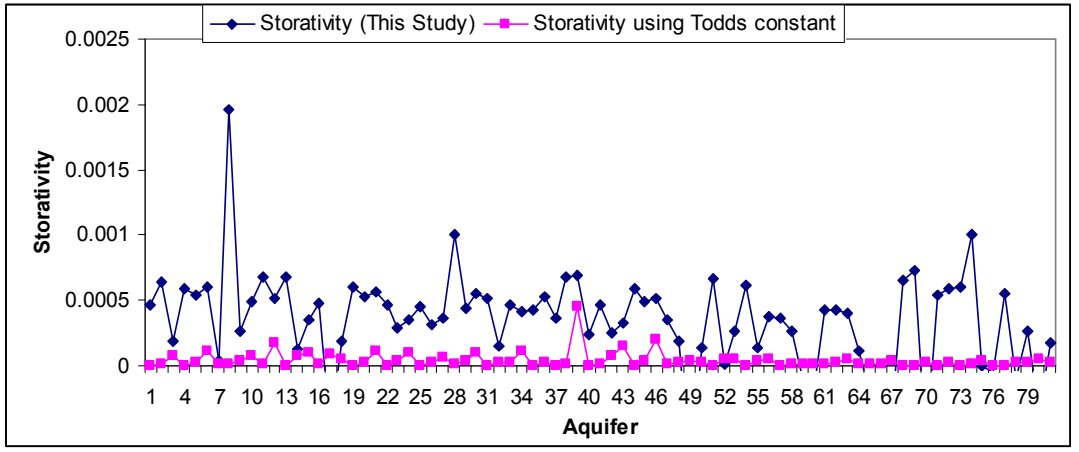

Figure 5. Comparison of storativity determined using compressibility and porosity values from this study in Freeze and Cherry (1979) equation and Todd; 1980, Lowman; 1979 equation.

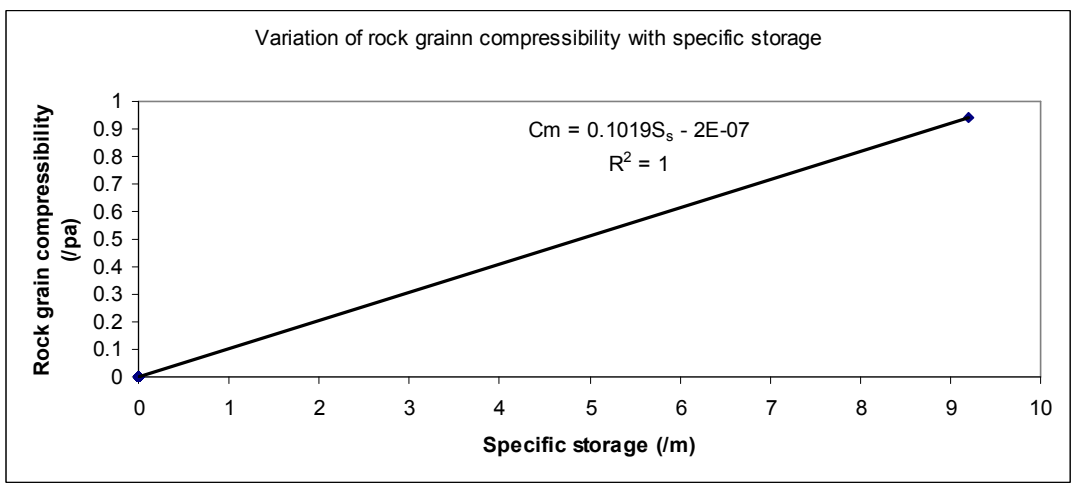

Figure 6. Variation of rock grain compresibilit with aquifer specific storage.

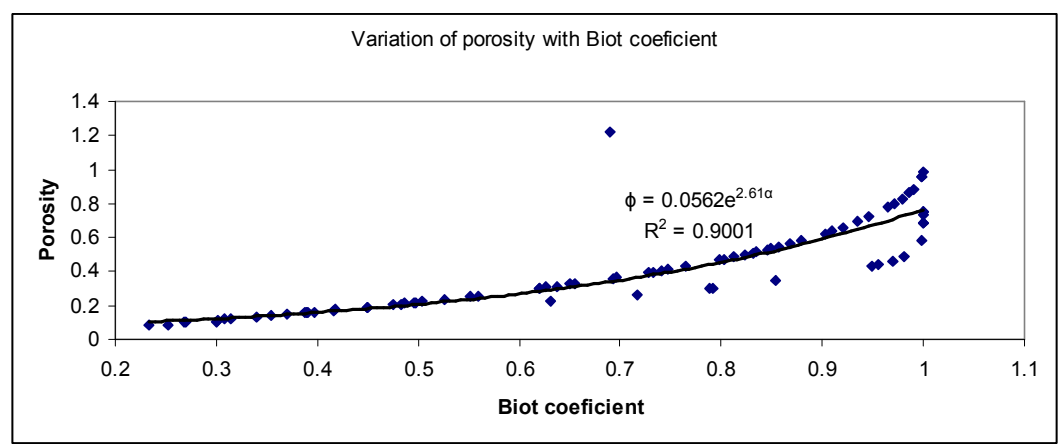

Figure 7. Variation of porosity with aquifer Biot Coefficient

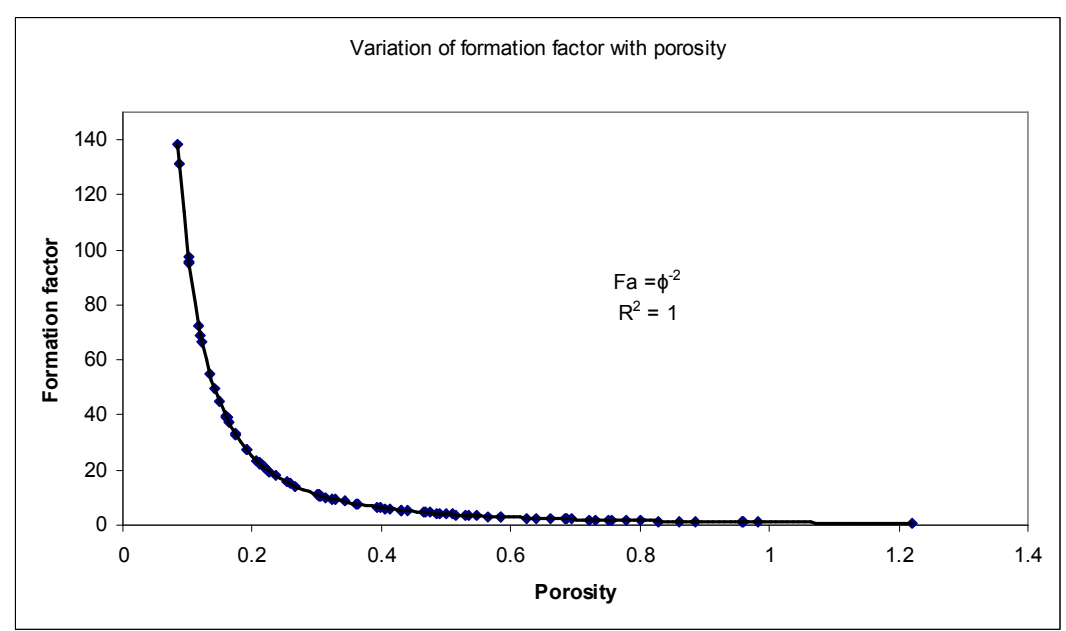

Figure 8. Variation of formtion factor with aquifer porosity. 


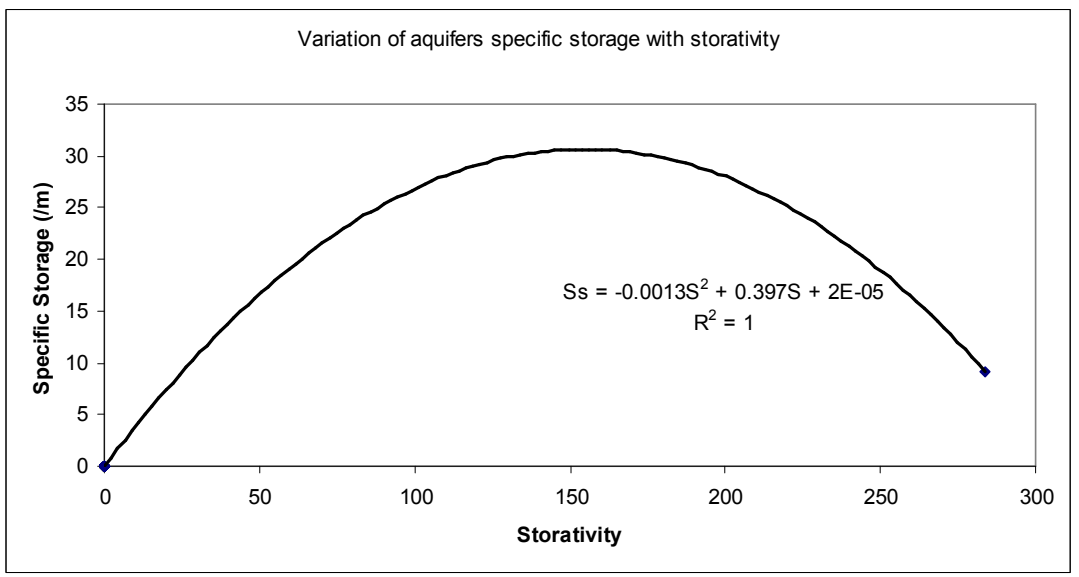

Figure 9. Correlation of aquifer specific storage with storativity.

\section{Conclusion}

The hitherto method of estimating aquifer storativity using the equation of $[17,18]$ assumes that all rocks irrespective of lithology, porosity, compressibility and fractures have the same specific storage. This assumption is faulty and in this study, it is evident that all rocks predictably have different specific storage due to varying composition, porosity and compressibility. Rock elasticity is a function of its compressibility; and a rocks ability to store fluids such as water is based on its porosity. Since the release of groundwater into an abstraction well comes from elastic storage and gravitational drainage as result of the overburden loading, its conclusive to say assuming a constant specific storage value of $3.0 \times 10^{-6}$ for all rocks in the storativity equation $[17,18]$ is misleading. The use of dynamic methods relying on the interpretation of geophysical data which probe into the subsurface can offer useful data on the knowledge of the earth which can be useful in predicting the mechanical properties of subsurface rocks and their response to stress should be adopted.

Table 2. Geoelectric layers, thickness, and depth of occurrence the study locations.

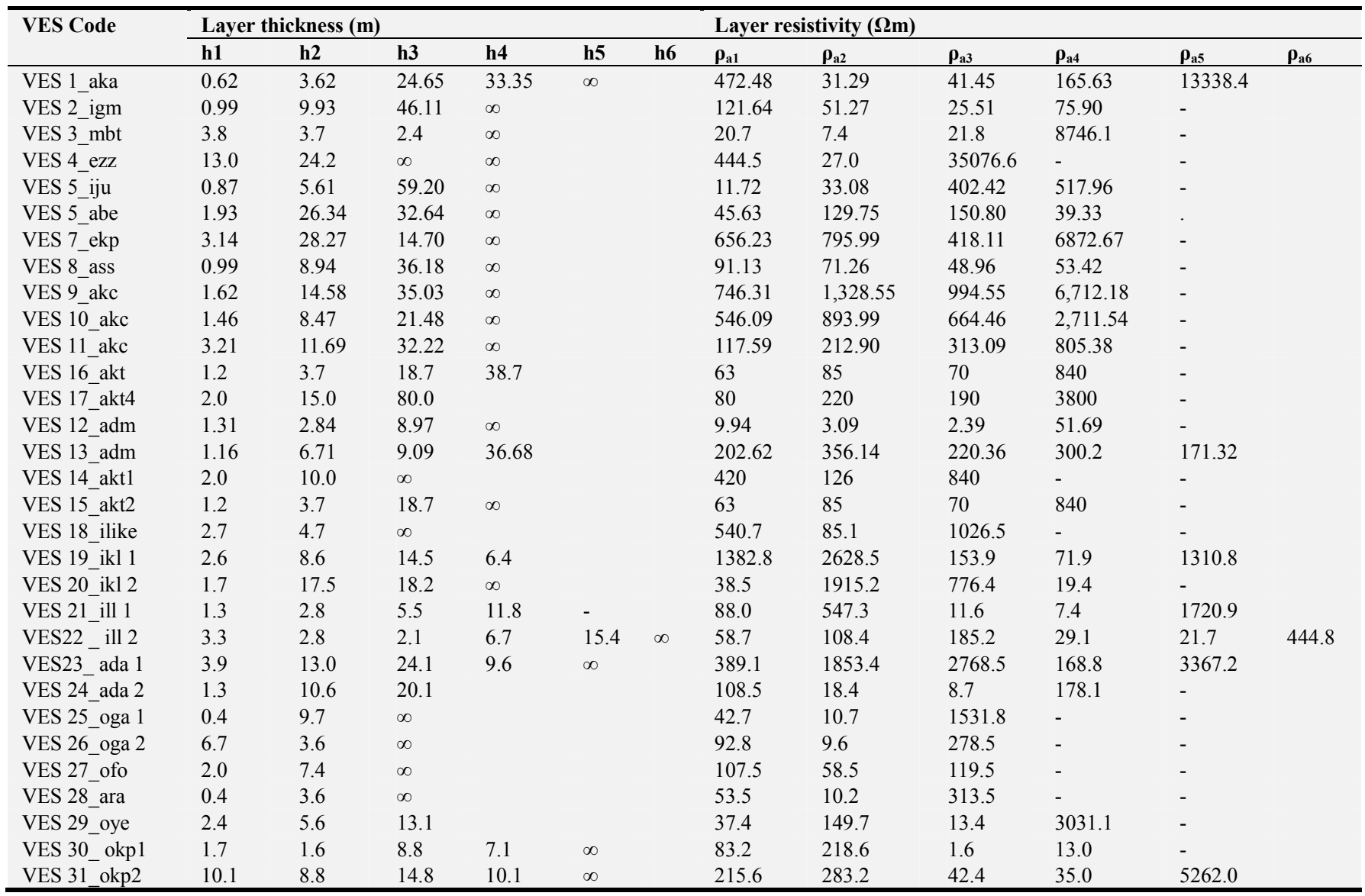


Table 3. Geomechanical properties of interpreted aquiferous rock layers and their storage properties.

\begin{tabular}{|c|c|c|c|c|c|c|c|c|c|c|c|c|}
\hline $\begin{array}{l}\text { Location \& } \\
\text { VES No }\end{array}$ & $\begin{array}{l}\text { Layer } \\
\text { Resistivity } \\
\text { (Ohm-m) }\end{array}$ & $\begin{array}{l}\text { Depth } \\
\text { (m) }\end{array}$ & $\begin{array}{l}\text { Thickness } \\
\text { (m) }\end{array}$ & $\begin{array}{l}\text { Interpreted } \\
\text { Lithology }\end{array}$ & $\begin{array}{l}\sigma_{\mathrm{z}} \\
(\mathrm{MPa})\end{array}$ & $C_{b}(/ \mathrm{kPa})$ & $\mathrm{C}_{\mathrm{g}}(/ \mathrm{kPa})$ & Biot & $\mathbf{F}$ & $\Phi$ & $\mathbf{S}_{\mathrm{s}}$ & $\mathbf{S}$ \\
\hline VES 1_aka & 165.63 & 62.24 & 24.62 & Sandstone & 1.59 & $6.94 \times 10^{-7}$ & $1.16 \times 10^{-6}$ & 0.68 & 8.28 & 0.35 & $1.142 \times 10^{-5}$ & 0.0004 \\
\hline VES 2_igm & 75.90 & 46.11 & $\infty$ & Fractured shale & 1.43 & 0.70038 & 1.28392 & 0.83 & 3.80 & 0.51 & 10.52 & 219.75 \\
\hline VES 3_mgt & 21.8 & 30 & 20 & $\begin{array}{l}\text { Fractured } \\
\text { Saprolite }\end{array}$ & 0.23 & $4.17 \times 10^{-5}$ & $8.3 \times 10^{-5}$ & 0.99 & 1.09 & 0.96 & 0.0008 & 0.002 \\
\hline VES 4 ezz & 27 & 30 & 17.0 & Sandstone & 0.94 & $1.04 \times 10^{-6}$ & $2.06 \times 10^{-6}$ & 0.99 & 1.35 & 0.86 & $2.02 \times 10^{-5}$ & 0.0005 \\
\hline VES 5_iju & 402.42 & 46.11 & 14.70 & Sandstone & 1.67 & $5.88 \times 10^{-7}$ & $8.84 \times 10^{-7}$ & 0.50 & 20.12 & 0.22 & $8.67 \times 10^{-6}$ & 0.0005 \\
\hline VES 6_abe & 150.80 & 65 & $\infty$ & Sandstone & 1.55 & $6.44 \times 10^{-7}$ & $1.09 \times 10^{-6}$ & 0.70 & 7.54 & 0.36 & $1.073 \times 10^{-5}$ & 0.0004 \\
\hline VES 7_ekp & 418.11 & 51.23 & 35.03 & $\begin{array}{l}\text { Weathered } \\
\text { Granites }\end{array}$ & 1.12 & $8.55 \times 10^{-7}$ & $1.28 \times 10^{-6}$ & 0.50 & 20.9 & 0.21 & $1.23 \times 10^{-5}$ & 0.0002 \\
\hline VES 8_ass & 48.96 & 46.11 & 36.18 & $\begin{array}{l}\text { Weathered } \\
\text { granites/gneiss }\end{array}$ & 1.17 & $8.38 \times 10^{-7}$ & $1.60 \times 10^{-6}$ & 0.90 & 2.45 & 0.64 & $1.57 \times 10^{-5}$ & 0.0006 \\
\hline VES 9_akc 1 & 994.55 & 51.23 & 35.03 & $\begin{array}{l}\text { Weathered } \\
\text { granites }\end{array}$ & 1.30 & $7.54 \times 10^{-7}$ & $1.02 \times 10^{-6}$ & 0.35 & 49.7 & 0.14 & $1.00 \times 10^{-5}$ & 0.0004 \\
\hline VES 10_akc 2 & 664.46 & 31.41 & 21.48 & $\begin{array}{l}\text { Weathered } \\
\text { granitic gneiss }\end{array}$ & 0.79 & $1.23 \times 10^{-6}$ & $1.74 \times 10^{-6}$ & 0.42 & 33.2 & 0.17 & $1.71 \times 10^{-5}$ & 0.0004 \\
\hline VES 11_akc 3 & 313.09 & 47.12 & 32.22 & $\begin{array}{l}\text { Weathered } \\
\text { Granites }\end{array}$ & 1.2 & $8.20 \times 10^{-7}$ & $1.27 \times 10^{-6}$ & 0.56 & 15.7 & 0.25 & $1.71 \times 10^{-5}$ & 0.0006 \\
\hline VES 12_akt 3 & 840 & 38.7 & 20 & Sandstone & 0.98 & $1.02 \times 10^{-6}$ & $1.41 \times 10^{-6}$ & 0.38 & 42 & 0.15 & $1.38 \times 10^{-5}$ & 0.0003 \\
\hline VES 13 akt 4 & 190 & 65 & 80 & Sandstone & 2.04 & $4.89 \times 10^{-7}$ & $8.06 \times 10^{-7}$ & 0.65 & 9.5 & 0.32 & $7.91 \times 10^{-6}$ & 0.0005 \\
\hline VES 14_akt 1 & 840 & 30 & 20 & Sandstone & 0.75 & $1.32 \times 10^{-6}$ & $1.83 \times 10^{-6}$ & 0.38 & 42 & 0.15 & $1.80 \times 10^{-5}$ & 0.0004 \\
\hline VES 15_akt 2 & 840 & 38.7 & 20 & Sandstone & 0.98 & $1.02 \times 10^{-6}$ & $1.41 \times 10^{-7}$ & 0.87 & 42 & 0.15 & $6.55 \times 10^{-6}$ & 0.00032 \\
\hline VES 16_adm & 300.2 & 53.64 & 36.68 & Sandstone & 1.36 & $7.33 \times 10^{-7}$ & $1.14 \times 10^{-6}$ & 0.56 & 15.0 & 0.26 & $1.12 \times 10^{-5}$ & 0.0004 \\
\hline VES 17_akt 2 & 840 & 38.7 & 20 & Sandstone & 0.98 & $1.02 \times 10^{-6}$ & $1.41 \times 10^{-7}$ & 0.87 & 42 & 0.15 & $6.55 \times 10^{-6}$ & 0.0003 \\
\hline VES 18 ikl1 & 76.9 & 32.1 & 6.4 & Sandstone & 0.81 & $1.20 \times 10^{-6}$ & $2.20 \times 10^{-6}$ & 0.83 & 3.85 & 0.51 & $2.16 \times 10^{-5}$ & 0.0001 \\
\hline VES 19 ikl2 & 776.4 & 37.4 & 18.2 & Sandstone & 0.94 & $1.05 \times 10^{-6}$ & $1.47 \times 10^{-6}$ & 0.39 & 38.8 & 0.16 & $1.44 \times 10^{-5}$ & 0.0003 \\
\hline VES20 ill2 & 21.7 & 30.3 & 15.4 & Sandstone & 0.75 & $1.32 \times 10^{-6}$ & $2.63 \times 10^{-6}$ & 0.99 & 1.08 & 0.96 & $2.58 \times 10^{-5}$ & 0.0004 \\
\hline VES $21^{-}$oga 1 & 278.5 & 45 & 35.3 & Sandstone & 1.1 & $8.77 \times 10^{-7}$ & $1.51 \times 10^{-6}$ & 0.72 & 13.9 & 0.27 & $1.48 \times 10^{-5}$ & 0.0005 \\
\hline VES 22 okp 1 & 35 & 43.8 & 10.1 & Sandstone & 1.1 & $9.01 \times 10^{-7}$ & $1.80 \times 10^{-6}$ & 1 & 1.75 & 0.75 & $1.77 \times 10^{-5}$ & 0.0001 \\
\hline
\end{tabular}

$\rho_{\mathrm{a}}=$ Apparent resistivity $(\Omega \mathrm{m}), \sigma_{\mathrm{z}}=$ Vertical stress $(\mathrm{mpa}), \mathrm{C}_{\mathrm{b}}=$ Bulk compressibility $(/ \mathrm{Pa}), \mathrm{C}_{\mathrm{g}}=$ Grain compressibility $(/ \mathrm{Pa})$, Biot $=$ Biot Coefficient, $\mathrm{F}=$ Formation factor, $\varphi=$ Porosity (decimal), $\mathrm{S}_{\mathrm{s}}=$ Specific Storage $\left({ }^{-\mathrm{m}}\right), \mathrm{S}=$ Storativity.

\section{References}

[1] Green, D. H. and Wandg, H. F. (1990). Specific storage as poroelastic coefficient. Water Resources research, 26 (7). Pp. 1631 - 1637. Doi: 10.1029/WR026i007p01631.

[2] Fetter, C. W. (1990). Applied Hydrogeology, 2nd Edn. New Delhi: CBS Publishers and Distributors. 991pages.

[3] Younger, P. L. (1993). Simple generalized methods for estimating aquifer storage parameters. Quarterly Journal of Engineering Geology, 26. Pp. 127-135.

[4] Shendi, E. H. (2008). Electrical Prospecting Methods. Department of Geology, Faculty of Science, Suez Canal University Monograph $126 \mathrm{pp}$.

[5] Wright, E. P. (1990). Basement aquifers in Africa. Commonwealth Science Council Tech. Paper. 273 (2) pp. 349-363.

[6] Abija, F. A., Essien, N. U., Abam, T. K. S and Ifedotun, A. I. (2019). Assessment of aquifer hydraulic properties, groundwater potential; and vulnerability integrating geoelectric methods with SRTM-DEM and LANDSAT-7 ETM lineament analysis in parts of Cross River State, Nigeria. London Journal of Research in Science: Natural and Formal. Vol. 19, Issue 4, Compilation 1.

[7] Orajaka, S. O., 1964. Geology of the Obudu area, Ogoja Province, Eastern Nigeria. Le Naturalist Canadien, XC1 (3):
73-78.

[8] Umeje, A. C., 1988. The Precambrian of part of southeastern Nigeria: a magmatic and tectonic study. In: P. O. Oluyide (coordinator), Precambrian Geology of Nigeria. Geol. Surv. Nigeria. Publ., 69-75.

[9] Fitton J. G. (1980). The Benue trough and Cameroon line: A Migrating rift System in West Africa. Earth and Planetary Science Letters, 51 (1980) 132-138.

[10] Ekwueme, B. N., 1990. Petrology of Southern Obudu Plateau, Bamenda Massif, Southeastern Nigeria. In: G. Rocc; and M. Deschamps (Coordinators) Recent Data in African Sciences, CIFEG Occas. Publi. 22: 155-158.

[11] Ukwang, E. E., 1998. Petrology and Geochemistry of Uwortung-Utugwang area, Obudu Plateau, southeastern Nigeria. Unpubl. M. Sc. Thesis, Univ. Calabar, Nigeria, 87 pp.

[12] Ukaegbu, V. O., 2003. The Petrology and Geochemistry of parts of Obudu Plateau Bamenda massif, southeastern Nigeria. Unpubl. Ph. D. Thesis, Univ. Port Harcourt Nigeria. 321 pp.

[13] Ekwueme, B. N., Nyong, E. E. and Petters, S. W., 1995. Geological Excursion Guide Book to Oban massif, Calabar Flank and Mamfe Embayment, Southeastern Nigeria. DecFord Publi., Calabar, Nigeria, 36.

[14] Reyment, R. A., (1965). Aspects of Geology of Nigeria. Ibadan Univ. Press, Ibadan.

[15] Freeze, R. A. and Cherry, J. A. (1979). Groundwater. New Jersey: Prentice Hall. 
[16] Lohman, S. W. (1972). Groundwater hydraulics. USGS professional paper, Vol. 7, pp. 708.

[17] Todd, D. K. (1980). Groundwater Hydrology, $2^{\text {nd }}$ edn. New York: John Wiley and Sons. 552pages.

[18] Donaldson, E. C. (1995). Simulation of compaction due to fluid withdrawal. In: Chilingorian, G. H., E. C.

[19] Hoek, E. and Brown, E. T. (1980). Underground excavation in rock. Institution of Mining and Metallurgy, London. 527 pp.

[20] www.geopixel.co.uk.

[21] Terzaghi, K. V. 1924. Die Theorie der hydrodynamischen Spannungserscheinungen und ihr erdbautechnisches Anwendungsgebiet. Proc., First International Congress for Applied Mechanics, Delft, The Netherlands, Pp 22-26 April, 288-294.

[22] Biot, M. A. 1941. General theory of three - dimensional consolidation. J. Appl. Phys. 12 (2): Pp 155-164. http://dx.doi.org/10.1063/1.1712886.

[23] Biot, M. A. 1956. General solutions of the equations of elasticity and consolidation for a porous material. Journal of Applied Mechanics, 23 Pp 91-96.
[24] Geertsma, J. (1957) The effect of fluid pressure decline on volumetric changes of porous rocks. Society of Petroleum Engineers, SPE-728-G.

[25] Skempton, A. W. (1961) Effective Stress in Soils, Concrete and Rocks, in Selected Papers on Soil Mechanics, pp. 106118 .

[26] Krief, M., Garat, J., Stellingwerff, J., and Ventre, J. (1990). A petrophysical interpretation using the velocity of $\mathrm{P}$ and $\mathrm{S}$ waves (Full waveform sonic $\log$ ). The Log Analysis, 355, November - December.

[27] Archie, G. E., (1942). The Electrical Resistivity Log as an Aid in Determining some Reservoir Characteristics. Trans. Am. Inst. Min. Eng. Vol. 146, pp. 54-62.

[28] Bernard, J. (2003), "Short notes on the principles of geophysical methods for groundwater investigations", Unpublished notes, Terraplus, 8 pp.

[29] Schlumberger. 1985. Well evaluation conference, Schlumberger Technical Services INC Vol. 2, Pp 11-124. 